4-13-2006

\title{
Dam impacts on the Changjiang (Yangtze) River sediment discharge to the sea: The past 55 years and after the Three Gorges Dam
}

\author{
Z Yang \\ H Wang \\ Y Saito \\ JD Milliman \\ Virginia Institute of Marine Science \\ $\mathrm{KXu}$ \\ Virginia Institute of Marine Science
}

See next page for additional authors

Follow this and additional works at: https://scholarworks.wm.edu/vimsarticles

Part of the Sedimentology Commons

\section{Recommended Citation}

Yang, Z; Wang, H; Saito, Y; Milliman, JD; Xu, K; Qiao, S; and Shi, G, Dam impacts on the Changjiang (Yangtze) River sediment discharge to the sea: The past 55 years and after the Three Gorges Dam (2006). Water Resources Research, 42(4), W04407.

10.1029/2005WR003970

This Article is brought to you for free and open access by the Virginia Institute of Marine Science at W\&M ScholarWorks. It has been accepted for inclusion in VIMS Articles by an authorized administrator of W\&M ScholarWorks. For more information, please contact scholarworks@wm.edu. 
Authors

Z Yang, H Wang, Y Saito, JD Milliman, K Xu, S Qiao, and G Shi 


\title{
Dam impacts on the Changjiang (Yangtze) River sediment discharge to the sea: The past 55 years and after the Three Gorges Dam
}

\author{
Z. Yang, ${ }^{1,2}$ H. Wang, ${ }^{1,2}$ Y. Saito, ${ }^{3}$ J. D. Milliman, ${ }^{4}$ K. Xu, ${ }^{4}$ S. Qiao, ${ }^{1,2}$ and G. $\mathrm{Shi}^{5}$ \\ Received 18 January 2005; revised 17 October 2005; accepted 9 November 2005; published 15 April 2006.
}

[1] In 5 recent years (2000-2004), the Changjiang (Yangtze) River has discharged past Datong (600 km from the river mouth) an average of $\sim 250$ million tons (mt) of sediment per year, a decrease of more than $40 \%$ since the 1950 s and 1960 s, whereas water discharge at Datong has increased slightly. Water and sediment discharge data from the upper, middle, and lower reaches of the river suggest that the reduction of the Changjiang sediment load has occurred in two phases between 1950 and 2002: following the closure of the Danjiangkou Reservoir on the Hanjiang tributary in 1968 and following the installation of numerous dams and water-soil conservation works in the Jialingjijang catchment after 1985. As the Three Gorges Dam (TGD) started operating in 2003, the Changjiang entered a third phase of sediment reduction with annual sediment loads at Datong less than $200 \mathrm{mt} / \mathrm{yr}$. Upon completion of the Three Gorges Dam (TGD) in 2009, the sediment load at Datong will decrease to $\sim 210 \mathrm{mt} / \mathrm{yr}$ for the first 20 years, then will recover to $\sim 230 \mathrm{mt} / \mathrm{yr}$ during $2030-2060$, and will reach $\sim 310 \mathrm{mt} / \mathrm{yr}$ during 2060-2110. From the sediment budget and sediment erosion data for the Changjiang subaqueous delta, it can be assumed that the delta will be eroded extensively during the first five decades after TGD operation and then will approach a balance during the next five decades as sediment discharging from TGD again increases.

Citation: Yang, Z., H. Wang, Y. Saito, J. D. Milliman, K. Xu, S. Qiao, and G. Shi (2006), Dam impacts on the Changjiang (Yangtze) River sediment discharge to the sea: The past 55 years and after the Three Gorges Dam, Water Resour. Res., 42, W04407, doi:10.1029/2005WR003970.

\section{Introduction}

[2] The Changjiang (Yangtze) River is Asia's longest $(6300 \mathrm{~km})$ river and the fifth largest in the world in terms of water discharge $\left(920 \mathrm{~km}^{3} / \mathrm{yr}\right)$ and historically fourth largest in sediment discharge, 480 million tons per year (mt/yr) [Milliman and Syvitski, 1992]. However, over the past five decades the river's sediment discharge has decreased steadily [International Research and Training Center on Erosion and Sedimentation (IRTCES), 2000, 2001, 2002, 2003], whereas water discharge at Datong has increased slightly. According to data from the Changjiang Water Resources Commission (CWRC), the mean annual sediment load recorded at the Datong hydrographic station, $600 \mathrm{~km}$ landward of the East China Sea, has been $320 \mathrm{mt} / \mathrm{yr}$ between 1986 and 2004, which is only $65 \%$ of the $490 \mathrm{mt} / \mathrm{yr}$ (average of 1951-1968). Moreover, sediment load past Datong in 2004 was only $147 \mathrm{mt}(\mathrm{Q}$. X. Xu, personal communication, 2005), or 30\% of the 1951-1968 average.

\footnotetext{
${ }^{1}$ College of Marine Geosciences, Ocean University of China, Qingdao, China.

${ }^{2}$ Key Laboratory of Seafloor Science and Exploration Technology, Ocean University of China, Qingdao, China.

${ }^{3}$ Institute of Advanced Industrial Science and Technology, Geological Survey of Japan, Tsukuba, Japan.

${ }^{4}$ Virginia Institute of Marine Science, Gloucester Point, Virginia, USA.

${ }^{5}$ Changjiang Water Resource Commission, Wuhan, China.
}

Copyright 2006 by the American Geophysical Union. 0043-1397/06/2005WR003970
[3] This decline in Changjiang sediment discharge has garnered increased attention and concern. Its catchment $\left(1.8 \times 10^{6} \mathrm{~km}^{2}\right)$ is home to about 400 million people, $6.6 \%$ of the world's population [United Nations Department of Economic and Social Affairs, 2001], and as the Shanghai metropolitan region lies on the Changjiang delta, the total catchment provides $42 \%$ of China's GDP [Chen et al., 2001]. The river's flood and droughts affect not only the lives of the people living in the catchment but also the nutrient content and salinity of ecosystems along the East China Sea and Sea of Japan. Since the late 1980s China has become the world largest consumer of chemical fertilizers, and huge quantities are eroded and transported downstream from the cultivated lands within the Changjiang watershed, causing eutrophication of coastal waters [Zhang et al., 1995]. Therefore the decreasing Changjiang sediment load can have both regional and global significance.

[4] The situation is complicated by construction of the Three Gorges Dam (TGD). Although the project will not be completed until 2009, the $175 \mathrm{~m}$ high dam [ $L i, 1997]$ began to retain water and sediment in June 2003 as the dam rose to water level of $135 \mathrm{~m}$. According to its design plan, the TGD will trap $70 \%$ of the sediment discharge from the upper reaches of the river at the first two decades after 2009; over its first 100 years, the reservoir behind the dam is expected to retain more than $44 \%$ of the river's sediment from the upper reaches [Yang et al., 2002]. Since the upper reaches of the river discharge $\sim 500 \mathrm{mt} / \mathrm{yr}$ of sediment (as measured at Yichang; see Figure 1), a loss of $70 \%$ could reduce the 


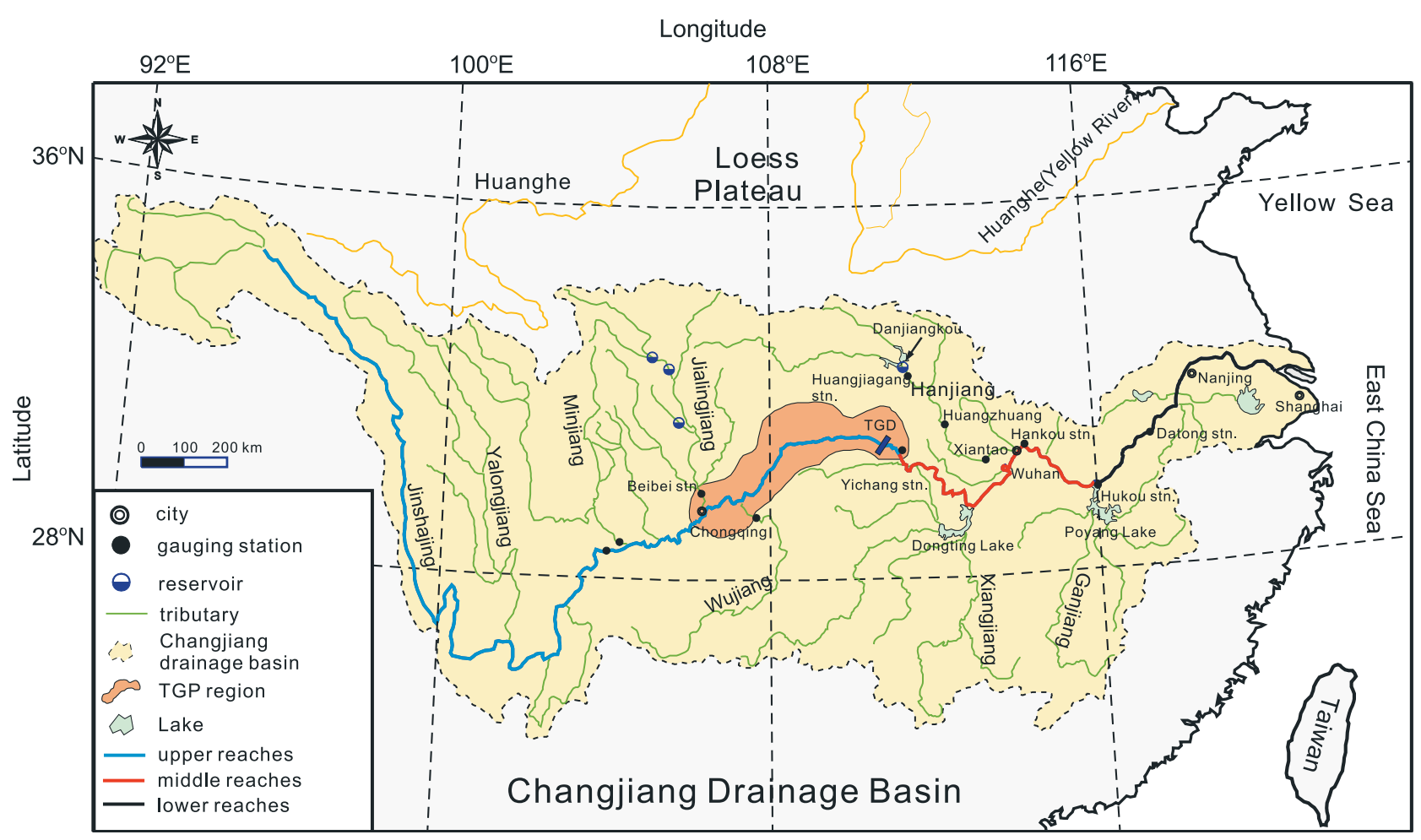

Figure 1. Map of the Changjiang (Yangtze) River: TGD, Three Gorges Dam; TGP, Three Gorges Project.

river's discharge to the East China Sea significantly. One possible consequence would be major coastal erosion to the Changjiang delta, the richest and most developed area in China. In addition, the South-to-North Water Transfer Project will remove $\sim 5 \%$ of the Changjiang water, leading to $\sim 3-5 \%$ sediment loss [Yang et al. 2002], which would finally impact the ecosystems of the Changjiang estuary and the adjacent sea [Chen and Chen, 2002].

[5] Previous studies, some of which are discussed in the following paragraphs, have concluded that the reduction of Changjiang sediment load has been the result of its 45,628 reservoirs (as of 1995), including 119 large ones [Wen et al., 1999; $A$. Xu, 2000]. It was indicated that the retention of sediment by reservoirs in many impounded basins exceeds 90\% [Meybeck, 2003]. The decrease of suspended solids due to the reservoir storage after damming has a stepwise character [Meade and Parker, 1985; Meybeck and Vorosmarty, 2005]. The Changjiang could be one of the best cases to illustrate how dams and reservoirs impact the river sediment flux to the oceans owing to large number of reservoirs constructed at different period during last 5 decades. Using water and sediment data from the major hydrological stations along the main stem and its main tributaries, we discuss the factors responsible for the declining sediment load. The impacts of the TGD on sediment discharge and delta erosion are then briefly considered.

\section{Background}

[6] In recent years many articles, particularly in the Chinese literature, have discussed variations in the Changjiang's water and sediment discharge, but most of them have dealt with the river's upper and middle reaches, which would affect directly the TGD project. Many of the papers dealing with downstream aspects, however, have been limited to data prior to 1990 . On the basis of a data set of 250 stations in the river's upper reaches for the period up to 1988, Higgitt and Lu [2001] and Lu and Higgitt [2001] concluded that, despite evidence of increased sediment erosion within tributary drainage basins, the long-term sediment yield showed no increase because of the construction of numerous dams, a point also made by $J . X u$ [2000]. Using primarily historical data for main hydrologic stations up to 1980, for instance, Chen et al. [2001] found a decadal scale of decreasing sediment load in the upper and middle reaches of the river (Yichang and Hankou stations, respectively), caused by numerous dams in the upper drainage basin; but they concluded that sediment discharge at Datong was quite stable. Shen [2001], in contrast, showed that the annual Datong sediment load between 1951 and 2000 showed a distinct downward trend, perhaps the result of changing precipitation in the high sediment yield areas in the upper reaches of the drainage basin. The Changjiang Water Conservation Commission also showed a downward trend in sediment discharge at the upper, middle and lower reaches of the river (Yichang, Hankou and Datong, respectively), but offered no explanation as to its cause.

[7] Recently, Yang et al. [2002, 2003] described a decadal scale downward decrease in sediment load at the Yichang and Datong stations between the late 1960s and 2000, the result of the many dams in the catchment. Yang et al. calculated that dams on the upper reaches of the Changjiang basin captured $230 \mathrm{mt}$ in 1990 . The storage capacity is also seen by the Danjiangkou Reservoir, largest on the Hanjiang tributary, which alone has captured $50 \mathrm{mt}$ of sediment since 1968. On the basis of the relationship between sediment 
Table 1. Hydrological Settings of the Changjiang: Mainstream and Major Tributaries ${ }^{\mathrm{a}}$

\begin{tabular}{|c|c|c|c|c|c|c|c|c|}
\hline & \multirow{2}{*}{\multicolumn{3}{|c|}{ Mainstream }} & \multicolumn{5}{|c|}{ Tributary } \\
\hline & & & & \multicolumn{4}{|c|}{ Upper } & \multirow{2}{*}{$\frac{\text { Middle/Lower }}{\text { Hanjing }}$} \\
\hline & Upper (Above Yichang) & Middle (Yichang-Hukou) & Lower (Hukou) & Jinshajiang & Minjiang & Jialingjiang & Wujing & \\
\hline Length, km & 4,500 & 950 & 930 & 2,284 & 735 & 1,120 & 1,037 & 1,577 \\
\hline Basin area, $\mathrm{km}^{2}$ & $1,000,000$ & 680,000 & 120,000 & 344,000 & 133,000 & 160,000 & 87,920 & 159,000 \\
\hline Gauging station & Yichang & Hankou & Datong & Pinshan & Gaochang & Beibei & Wulong & Huangzhuang \\
\hline $\mathrm{Q}, \mathrm{km}^{3} / \mathrm{yr}$ & 440 & 710 & 910 & 150 & 90 & 65 & 50 & 50 \\
\hline $\mathrm{Q}_{\mathrm{s}}, \mathrm{mt} / \mathrm{yr}$ & 500 & 400 & 430 & 240 & 50 & 110 & 28 & 60 \\
\hline
\end{tabular}

${ }^{\mathrm{a}}$ Annual water discharge $(\mathrm{Q})$ and sediment load $\left(\mathrm{Q}_{\mathrm{s}}\right)$ are the averages between the 1950s and 2002 The figures for Huangzhuang are from IRTCES [2003].

reduction at Yichang and Datong, they calculated that the coastline Changjiang delta would be strongly eroded following completion of the TGD.

[8] However, a number of basic problems still remain unanswered.

[9] 1. It is difficult to calculate temporal and spatial variations of sediment discharge of the Changjiang, with its large number of tributaries, on the basis of data from only two gauging stations, Yichang and Datong.

[10] 2. Describing temporal variations of water discharge (Q) and sediment load $\left(\mathrm{Q}_{\mathrm{s}}\right)$ on the basis of decadal time intervals may not adequately describe both shorter- and longer-term change.

[11] 3. Post-1980s data must be considered in evaluating long-term change.

[12] 4. Evaluating the effect of reservoirs on $Q_{s}$ should be based on the contributions from the major tributaries, since, prior to the completion of the TGD in 2002, all Changjiang catchment dams save one (the Gezhouba low dam) were located on tributaries [IRTCES, 2001]. Yang et al. [2002], in contrast, considered only a single dam (Danjiangkou) on a single tributary (Hanjiang).

[13] 5. The effects of channel and floodplain deposition and scouring along the entire river path should be considered, particularly during large floods, such as in 1954 and 1998, when overbank flow has occurred.

[14] 6. Forecasting the effect of the TGD on Changjiang sediment discharge may not be valid unless the above factors are taken into account. All these problems, collectively, could result in misunderstanding the cause of sediment reduction and therefore promote errors in forecasting the impact of the TGD.

[15] In this paper we identify the key factors responsible for the change in Changjiang sediment discharge recorded by looking at hydrologic data from key gauging stations along the Changjiang and its main tributaries between 1950 and 2004. The data we used are from the CWRC and partly obtained from the River Sediment Bulletin of China [IRTCES, 2000, 2001, 2002, 2003] published by the Ministry of Hydrology of China.

\section{Decreasing Changjiang Sediment Discharge From 1950 to 2004}

\subsection{Selecting Key Hydrologic Data and Stations to Describe Temporal and Spatial Variations in Changjiang Water and Sediment Discharge}

[16] The Changjiang is generally considered in three sections. The upper reaches, from the river's source to
Yichang, are more than $4500 \mathrm{~km}$ long; the middle reaches, from Yichang to Hukou, are $950 \mathrm{~km}$ long; and the lower reaches, from Hukou to the river mouth at about $930 \mathrm{~km}$ long (Figure 1 and Table 1). From this 6300-km long river we have chosen data from four gauging stations, Yichang, representing the upper reaches, Luoshan and Hankou, representing the middle reaches, and Datong, representing the lower reaches (Figure 2) to describe temporal and spatial changes along the river's course. Although the impact of dams can be demonstrated to a large extent from these four stations, we also use some data from several tributary stations. Data used in this paper were taken in large part from CWRC records, including data recently released in the River Sediment Bulletin of China [IRTCES, 2000, 2001, 2002, 2003].

[17] The measurement of the river sediment load was carried out according to the national standard criterion. At a

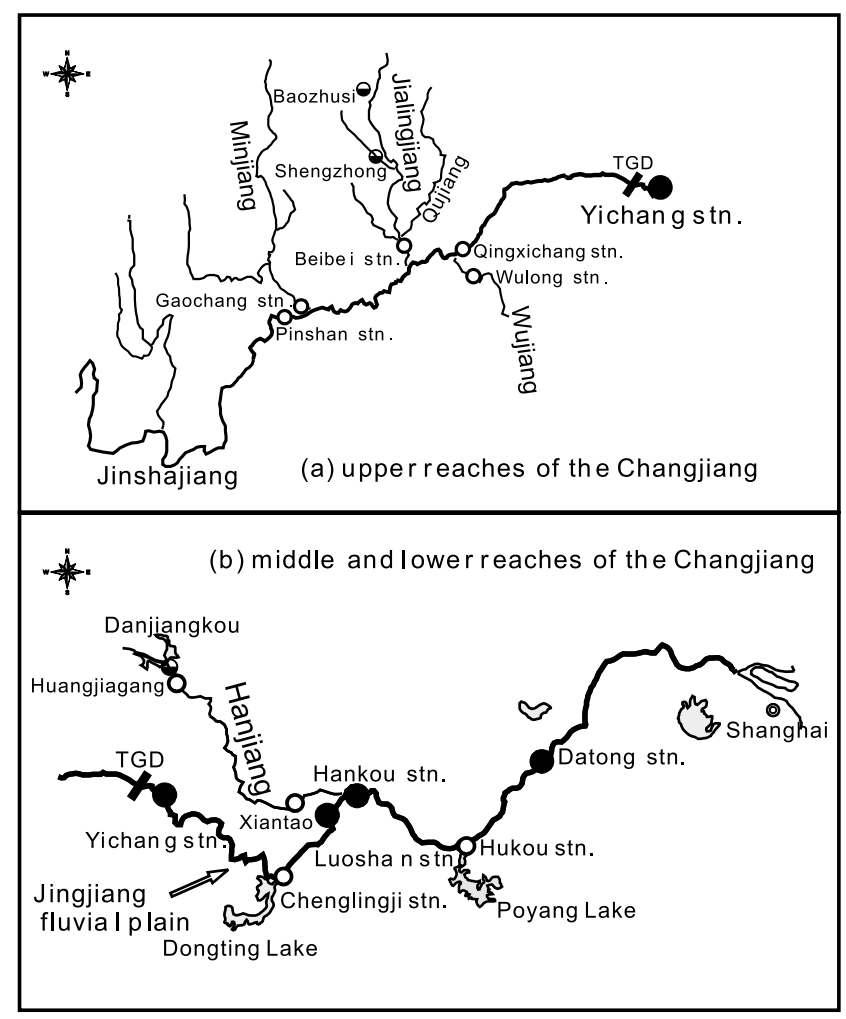

Figure 2. Location of key gauging stations and water reservoirs in the (a) upper and (b) middle and lower reaches of the Changjiang. 


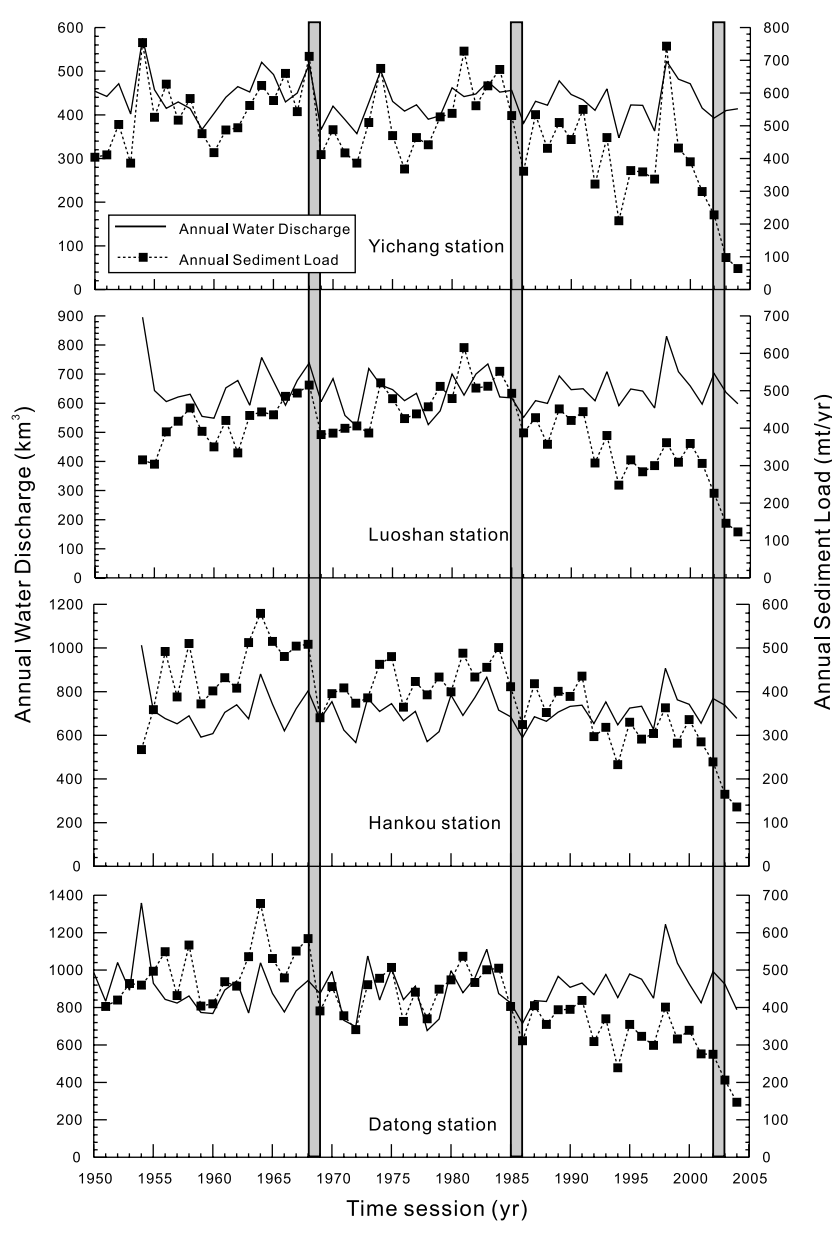

Figure 3. Annual water discharge and sediment loads at four key gauging stations, Yichang, Luoshan, Hankou, and Datong, 1950-2004. Initiations of the three phases of sediment reduction are designated by the vertical dashed lines.

fixed gauging section the water samples were taken across the water column as well as the flow discharge was recorded at certain time, from which the daily, monthly and annual suspended sediment loads passing the gauging section were derived.

[18] The mean water discharge $\left(440 \mathrm{~km}^{3} / \mathrm{yr}\right)$ and sediment load $(500 \mathrm{mt} / \mathrm{yr})$ recorded at Yichang from 1950 to 2002 represents water and sediment derived from Tibet and the Sichuan basin (Table 1). These are the main sources of sediment reaching the middle and lower reaches of the river. Above Yichang the river flows through narrow gorges hemmed in by mountains and is fed by four major tributaries, for example, Jinshajiang, Minjiang, Jialingjiang and Wujiang, totally contributing more that $86 \%$ of the annual sediment load at Yichang (Table 1). Below Yichang the river meanders across the gentle Jingjiang fluvial plain (Figure 1), forming numerous lowland lakes, bypasses and swamps in which overbank sediments are deposited. Dongting Lake, the second largest lake in China, is linked to the Changjiang channel by three outlets (Figure 1) through which there is extensive water and sediment exchange. Of the total $167 \mathrm{mt} / \mathrm{yr}$ of sediment entering the lake, $132 \mathrm{mt}$ is from the Changjiang, and the rest is from the lake's tributaries. The sediment returned to the Changjiang, as recorded at the Chenglingji gauge (Figure 2) is $43 \mathrm{mt} / \mathrm{yr}$, meaning that $\sim 124 \mathrm{mt} / \mathrm{yr}$ is deposited in the lake [IRTCES, 2001]. The deposited sediment, however, can be resuspended and transported back into the river channel to compensate for any river channel scouring in the middle and lower reaches beyond Luoshan [Shi et al., 2002].

[19] Sediment records at Luoshan, which is located on the Changjiang below the Chenglingji station, are important because the measured sediment load $(410 \mathrm{mt} / \mathrm{yr})$ and water discharge $\left(645 \mathrm{~km}^{3} / \mathrm{yr}\right)$ between 1954 and 2002 represents practically all the sediment from the upper reaches that remains in the river after it passes the Jingiiang fluvial plain and Dongting Lake (Figure 2). The ability of the upper middle reaches to trap sediment was particularly obvious during the 1954 and 1998 floods, when the high annual sediment loads noted at Yichang station (750 and $740 \mathrm{mt} / \mathrm{yr}$, respectively) were not seen at the downstream stations; in fact, sediment loads at Luoshan, Hankou and Datong were slightly lower than normal during those flooding years (Figure 3). As the flood wave tops the Changjiang banks, it drives water onto the Jingjiang floodplain and into Dongting Lake (Figure 4). The ability of this area to trap sediment is reflected by the estimated 290 and $340 \mathrm{mt}$ difference between annual sediment loads at Yichang and Datong during 1954 and 1998, compared to an average difference of $68 \mathrm{mt}$ during ordinary years.

[20] The sediment load of $400 \mathrm{mt} / \mathrm{yr}$ and water discharge of $710 \mathrm{~km}^{3} / \mathrm{yr}$ (1954-2002) measured at Hankou, just downstream from the Hanjiang (Figure 1 and Table 1), largest tributary to the Changjiang, reflects additional input from the Hanjiang.

[21] Hukou station, located at the outlet of Poyang Lake, largest freshwater lake in China, is at the upstream end of the Changjiang's lower reaches (Figure 2). The annual contribution of $10 \mathrm{mt}$ of sediment and $150 \mathrm{~km}^{3}$ of water to the Changjiang from Poyang Lake (minus the $1 \mathrm{mt} / \mathrm{yr}$ contributed from the Changjiang to Poyang Lake) represents only $\sim 2 \%$ of the annual sediment load recorded at Datong. Because of its relatively minor role in the Changjiang sediment discharge, we do not discuss it further in this paper.

[22] Finally, the sediment load of $430 \mathrm{mt} / \mathrm{yr}$ and water discharge of $910 \mathrm{~km}^{3} / \mathrm{yr}$ measured at Datong between 1950 and 2002 represents the sediment carried from the Changjiang to the upper edge of the tidal wedge (Table 1). Although $\sim 10 \%$ of Datong's sediment load is deposited in the river channel before it reaches the East China Sea [Shen, 2001], the Datong sediment and water records are generally used to represent the Changjiang's mass flux to the sea. Therefore the sediment fluxes recorded at Yichang, Luoshan and Hankou basically control the Changjiang's sediment discharge at Datong and therefore to the sea, and variations at any one of these stations will affect a similar response at Datong.

\subsection{Decreased Changjiang Sediment Flux as Recorded at Datong Station}

[23] Sediment discharge between 1950 and 2002, as measured at Datong, decreased in two distinct phases. The first phase of reduction began in 1969 and the second in 1986, each represented by a distinct drop in the first year followed by a steady decline thereafter (Figure 3). If we take 


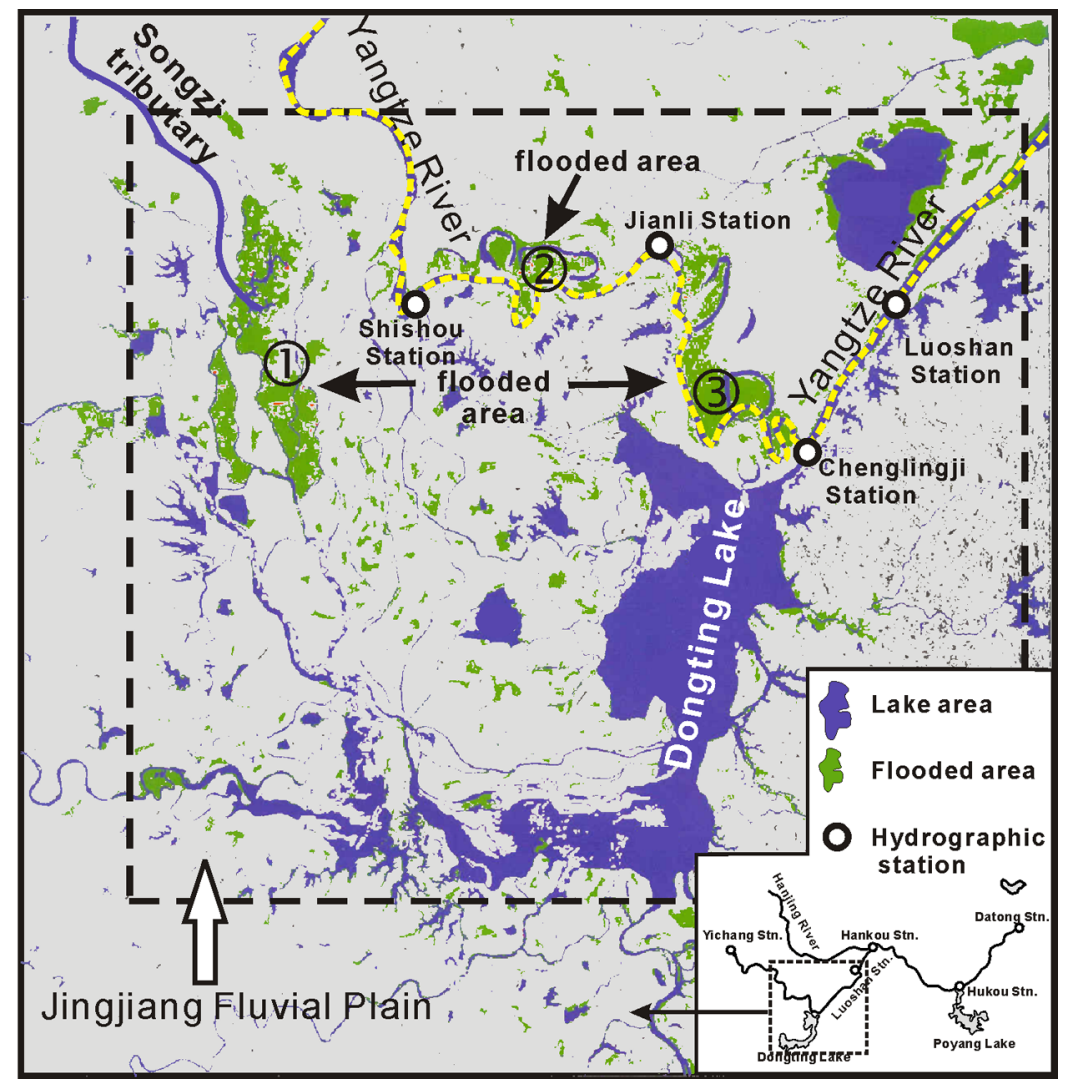

Figure 4. Flooded areas of the Jingjiang fluvial plain in 1998: flooded area downstream of the Songzi tributary, $340 \mathrm{~km}^{2}$ (number 1); flooded area between Shishou and Jianli stations, $123 \mathrm{~km}^{2}$ (number 2), and flooded area between Jianli and Chenglingji stations, $145 \mathrm{~km}^{2}$ (number 3 ).

the mean annual sediment load of $490 \mathrm{mt} / \mathrm{yr}$ for the 18 years between 1951 and 1968 to represent $100 \%$ of the baseline, then during the first 17-year phase from 1969 to 1985 , the sediment load decreased to about $440 \mathrm{mt} / \mathrm{yr}$, or about $90 \%$ of the baseline. During the second phase, 1986 to 2002, it decreased to $340 \mathrm{mt} / \mathrm{yr}$, or $70 \%$ of the $1951-1968$ baseline. As the Three Gorges Dam (TGD) started operating in 2003, the Changjiang entered a third phase of sediment reduction as annual sediment loads decreased to $180 \mathrm{mt} / \mathrm{yr}$, only $37 \%$ of the baseline (Table 2 and Figure 3).

3.2.1. First Phase of Sediment Reduction, 1969-1985

[24] Sediment discharge at Hankou has closely followed that at Datong (Figure 3). Between 1969 and 1985 the sediment load at Hankou decreased by $30 \mathrm{mt} / \mathrm{yr}$, and during the second phase it declined a further $90 \mathrm{mt} / \mathrm{yr}$ (Table 2 and Figure 3). In contrast, discharge at Yichang showed no distinct downward trend between 1950 and 1985, and at Luoshan the sediment load increased by $60 \mathrm{mt} / \mathrm{yr}$ (Figure 3), indicating that the first phase of sediment reduction cannot be attributed to any decrease in the upper reaches of the river. The decline must have occurred between Luoshan and Hankou, almost certainly in the sediment load of Hanjiang.

[25] The longest tributary to the Changjiang, the Hanjiang annually contributed $65 \mathrm{mt} / \mathrm{yr}$ to the Changjiang, through the Xiantao gauging section, located in the lower reaches of the Hanjiang. More than $95 \%$ of the sediment is suspended

Table 2. Sediment Loads $\left(\mathrm{Q}_{\mathrm{s}}\right)$ at Four Key Gauging Stations Along the Changiiang (Locations Shown in Figure 1) for Different Time Periods 1950-2004 and Major Events Responsible for the Sediment Reductions

\begin{tabular}{|c|c|c|c|c|c|c|c|c|}
\hline \multirow[b]{3}{*}{ Stations } & \multicolumn{8}{|c|}{ Sediment Discharge During Different Time Periods } \\
\hline & \multicolumn{2}{|c|}{$1950-1968^{\mathrm{a}}$} & \multicolumn{2}{|c|}{$1969-1985^{b}$} & \multicolumn{2}{|c|}{$1986-2002^{\mathrm{c}}$} & \multicolumn{2}{|c|}{$2003-2004^{\mathrm{d}}$} \\
\hline & $\mathrm{Q}_{\mathrm{s}}, \mathrm{mt} / \mathrm{yr}$ & Ratio, \% & $\mathrm{Q}_{\mathrm{s}}, \mathrm{mt} / \mathrm{yr}$ & Ratio, $\%$ & $\mathrm{Q}_{\mathrm{s}}, \mathrm{mt} / \mathrm{yr}$ & Ratio, \% & $\mathrm{Q}_{\mathrm{s}}, \mathrm{mt} / \mathrm{yr}$ & Ratio, $\%$ \\
\hline Yichang & 540 & 100 & 520 & 96 & 410 & 76 & 80 & 15 \\
\hline Luoshan & $410^{\mathrm{e}}$ & 100 & 470 & 115 & 350 & 85 & 135 & 33 \\
\hline Hankou & $450^{\mathrm{e}}$ & 100 & 420 & 93 & 330 & 73 & 150 & 33 \\
\hline Datong & $490^{\mathrm{e}}$ & 100 & 440 & 90 & 340 & 69 & 180 & 37 \\
\hline
\end{tabular}

${ }^{\mathrm{a}} 1950-1968$ values are considered as reference levels of $100 \%$.

${ }^{\mathrm{b}}$ The Danjiangkou Reservoir was completed in 1969, trapping most of the sediment from Hanjiang.

${ }^{\mathrm{c}}$ Numerous hydropower stations and the Water-Soil Conservation Project started in Jialingjiang basin

${ }^{\mathrm{d}}$ The Three Gorges Dam began trapping sediment from the upper Changjiang in June 2003.

${ }^{\mathrm{e}}$ Averages are from 1954 to 1968 at Luoshan and Hankou and 1951 to 1968 for Datong. 


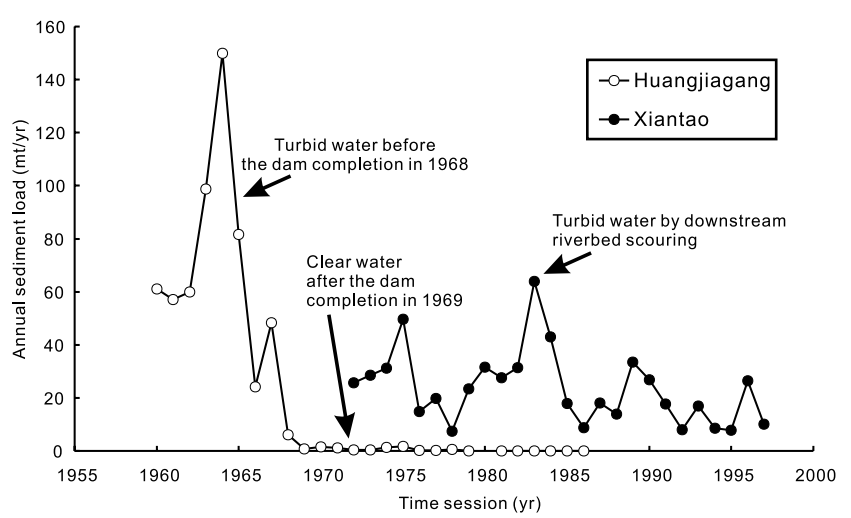

Figure 5. Annual sediment loads at Xiantao and Huangjiagang stations on the Hanjiang tributary.

[Li et al., 2000], mostly derived from the Loess Plateau, which lies in the upper reaches of the river (Figure 1). In 1959 construction of the Danjiangkou Reservoir was begun, the largest ever built in China to that date, with a water storage capacity of $17 \mathrm{~km}^{3}$. The reservoir continued to discharge turbid water until 1968, after which it began to trap sediment and the discharged water became sediment free. Although Han and Yang [2000] speculated on the role of the Danjiangkou Dam in reducing the post-1968 sediment load of the Changjiang, their analysis was more speculative than quantitative.

[26] Annual sediment load at the Huangjiagang gauge, located just below the Danjiangkou Reservoir (Figure 2), averaged $73 \mathrm{mt} / \mathrm{yr}$ before $1967 \mathrm{but}$ decreased to $0.8 \mathrm{mt} / \mathrm{yr}$ after 1968 (Figure 5), indicating a 99\% trapping efficiency. Nevertheless, an average of $24 \mathrm{mt} / \mathrm{yr}$ continued to be discharged through the Xiantao gauge after 1970, the result of scouring of the lower Hanjiang channel [Li et al., 2000] (Figure 5), as evidenced by increased grain size of both bed load and suspended sediments [Liu et al., 1998]. This gives a net reduction of sediment $\sim 41 \mathrm{mt} / \mathrm{yr}$ from Hanjiang tributary to the Changjiang compared to the previous $65 \mathrm{mt} / \mathrm{yr}$ at Xiantao gauge prior to the construction of Danjiangkou reservoir. The reduction of sediment load at Hankou during the first phase has been $30 \mathrm{mt}$, slightly less than the sediment reduction of Xiantao gauge. If the flood year of 1954 were excluded from the baseline, the annual sediment load at Hankou during 1955-1968 would be $460 \mathrm{mt} / \mathrm{yr}$, and the sediment reduction of the first phase would be $40 \mathrm{mt}$, almost equal to the decrease at Xiantao gauge. However, the increased grain size of sediment introduced by the Hanjiang presumably has resulted in greater deposition of sediment between Hankou and Datong, explaining the reduction in mean annual sediment load at Datong of $50 \mathrm{mt} / \mathrm{yr}$ (Table 2).

3.2.2. Second Phase of Sediment Reduction, 1986-2002 [27] After 1985, all four stations along the Changjiang exhibited a distinct downward trend in sediment load (with exception of the Yichang in 1998) (Figure 3). Whereas sediment loads at Yichang and Luoshan showed little change during the first phase of sediment reduction (sediment load actually increasing at Luoshan between 1969 and 1985), mean annual sediment loads at all four stations decreased by $\sim 20 \%$ relative to their 1969-1985 values (except for Luoshan by $\sim 30 \%$ ) (Table 2). Because the upper reaches of the river contribute $\sim 85-90 \%$ of the river's sediment supply, any change at Yichang was also experienced downstream.

[28] The mean annual sediment loads of four main contributors to upper Changjiang - the Jingshajiang (the upper part of the Changjiang), Minjiang, Jialingjiang and Wujiang (Figure 2 and Table 1) - total $\sim 430 \mathrm{mt} / \mathrm{yr}$, or $86 \%$ of the load measured at Yichang. Of the total of Yichang the Jinshajiang and Jialingjiang account for 47 and 24\%, respectively (Table 3 ). Sediment loads on the Jialingjiang after 1986 dropped significantly, the Wujiang and Minjiang decreased by $\sim 33 \%$ each, whereas the Jinshajiang's load increased slightly (Table 3 and Figure 6). The $100 \mathrm{mt} / \mathrm{yr}$ drop of the Jialingjiang (relative to 1954-1985 loads of $150 \mathrm{mt} / \mathrm{yr}$ ) at Beibei Gauge accounts for nearly all of the decrease in sediment load measured at Yichang $(120 \mathrm{mt})$ (compare Tables 2 and 3). About half of Jialingjiang load is derived from its upper reaches, which flows across the southern part of the Loess Plateau, and $\sim 20 \%$ comes from the Qujiang tributary, which joins the middle reaches of the Jialingjiang (Figure 2).

[29] The decrease in Jialingjiang sediment load comes in part from the 4537 reservoirs (with a total water storage capacity of $5.6 \mathrm{~km}^{3}$ ) built on the river before 1985. More important, however, has been construction of the Shengzhong Dam reservoir with storage capacity of $1.3 \mathrm{~km}^{3}$ (Figure 2) completed in 1986 [Mao and Pei, 2002] as well as other smaller reservoirs with a cumulative water capacity of $4 \mathrm{~km}^{3}$. In 1996 the large Baozhushi Reservoir $\left(2.6 \mathrm{~km}^{3}\right)$ began operation (Figure 2). Collectively, these reservoirs accounted for a $68 \mathrm{mt} / \mathrm{yr}$ decrease in Jialingjiang sediment load [Mao and Pei, 2002]. In addition, beginning in 1988, the Changzhi Water and Soil Conservation Project (WSCP) began reducing sediment erosion by improving vegetation cover and construction of many small coffer dams; collectively these soil conservation measures have accounted for another $30 \mathrm{mt} / \mathrm{yr}$ of decreased sediment load along the Jialingjiang [Shi et al., 2002]. Of the $100 \mathrm{mt} / \mathrm{yr}$ decrease in the Jialingjiang's sediment load during the

Table 3. Variation in Sediment Loads $\left(\mathrm{Q}_{\mathrm{s}}\right)$ for Four Tributaries Entering the Upper Reaches of the Changjiang, 1954-2004

\begin{tabular}{|c|c|c|c|c|c|c|c|c|c|}
\hline \multirow[b]{2}{*}{ Tributary } & \multirow[b]{2}{*}{ Station } & \multicolumn{2}{|c|}{$1954-1968$} & \multicolumn{2}{|c|}{$1969-1985$} & \multicolumn{2}{|c|}{$1986-2002$} & \multicolumn{2}{|c|}{$2003-2004$} \\
\hline & & $\mathrm{Q}_{\mathrm{s}}, \mathrm{mt} / \mathrm{yr}$ & Ratio, \% & $\mathrm{Q}_{\mathrm{s}}, \mathrm{mt} / \mathrm{yr}$ & Ratio, \% & $\mathrm{Q}_{\mathrm{s}}, \mathrm{mt} / \mathrm{yr}$ & Ratio, \% & $\mathrm{Q}_{\mathrm{s}}, \mathrm{mt} / \mathrm{yr}$ & Ratio, \% \\
\hline Jinshajiang & Pingshan & 250 & 100 & 210 & 84 & 270 & 108 & 150 & 60 \\
\hline Minjiang & Gaochang & 60 & 100 & 40 & 67 & 40 & 67 & 40 & 67 \\
\hline Jialingjiang & Beibei & 160 & 100 & 140 & 88 & 50 & 31 & 24 & 15 \\
\hline Wujiang & Wulong & 30 & 100 & 40 & 133 & 20 & 67 & 13 & 43 \\
\hline Total & & 500 & 100 & 430 & 86 & 380 & 76 & 230 & 46 \\
\hline
\end{tabular}




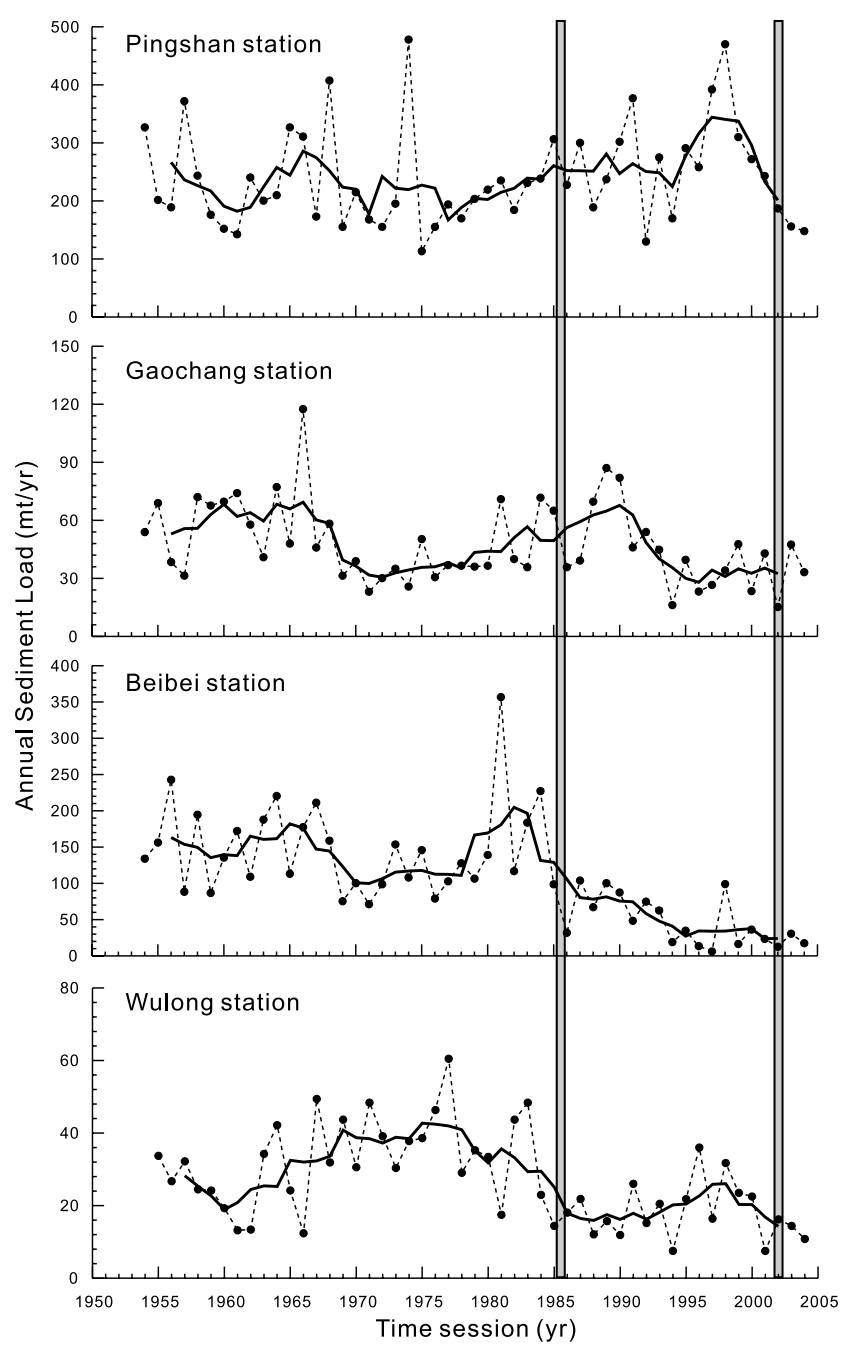

Figure 6. Annual sediment loads at four stations in the upper reaches of the Chanjiang: Jinshajiang (at Pingshan station), Minjiang (at Gaochang station), Jialingjiang (at Beibei station), and Wujiang (at Wulong station). The solid lines are 5-year running averages.

second phase of sediment reduction; therefore about $2 / 3$ was due to dam construction and $1 / 3$ to increased soil conservation.

\subsubsection{Third Phase of Sediment Reduction}

[30] The TGD has started retaining Changjiang water and sediment as its reservoir reached water level of $135 \mathrm{~m}$ in June, 2003, then to $139 \mathrm{~m}$ in November, 2003. While the mean sediment load at Qingxichang located in the upper reaches of TGD's reservoir (Figure 2) was $190 \mathrm{mt} / \mathrm{yr}$ between 2003 and 2004, the mean sediment load at Yichang located at the lower edge of the reservoir was only $80 \mathrm{mt} / \mathrm{yr}$. This represents a decrease of $330 \mathrm{mt} / \mathrm{yr}(\sim 60 \%)$ relative to 1986-2002 sediment loads at Yichang, or of $460 \mathrm{mt} / \mathrm{yr}$ ( $\sim 85 \%$ ) relative to $1951-1968$ values (Table 2$)$. That means $\sim 60 \%$ of sediment that entered into the reservoir was trapped by TGD, which caused a sharp sediment reduction at all the four stations along the Changjiang. The mean annual sediment load at Datong between 2003 and 2004 was $180 \mathrm{mt} / \mathrm{yr}$, which decreased dramatically by $160 \mathrm{mt} / \mathrm{yr}(\sim 30 \%)$ relative to $1986-2002$ values, or by
$310 \mathrm{mt} / \mathrm{yr}(\sim 60 \%)$ relative to $1951-1968$ values. (Figure 3 and Table 2). As sediment loads at Yichang after 2002 sharply reduced much earlier than that was expected, the river channel erosion in the middle and lower reaches seems to happen first in the Changjiang history.

[31] Meanwhile, the annual sediment loads of four main contributors to upper Changjiang - the Jingshajiang (the upper mainstream of the Changjiang), Jialingjiang, Wujiang and Minjiang in 2003-2004 have decreased to $230 \mathrm{mt} / \mathrm{yr}$, or $60 \%$ to their $1986-2002$ values and to less than $50 \%$ to their values in 1954-1968 (Figure 6 and Table 3), resulting in sediment reduction of the Changjiang upper reaches at Yichang and for the remainder of the Changjiang as well. The sharp reduction of sediment load from the upper reaches has caused the drastic sediment decrease at Yichang even earlier than the TGD operation. The annual sediment loads of four main contributors to upper Changjiang in 2001-2004 has been reduced to $270 \mathrm{mt} / \mathrm{yr}$, or to $\sim 50 \%$ of their 1954-1968 values (Figure 6). This situation accelerated the sediment reduction along the Changjiang in recent years, resulting in phase change of sediment reduction happening earlier in the upper reaches than that in lower reaches. After the TGD's completion in 2009 as the water level elevation reaches to $175 \mathrm{~m}[\mathrm{Li}, 1997]$ it is estimated that $\sim 70 \%$ of sediment will be retained within the reservoir for the first 2 decades, and more intensive sediment reduction is expected.

\subsection{Relations of Sediment Loads Between the Yichang and Datong Stations}

[32] The correlation of sediment load between Yichang and Datong from 1951 to 2002 is $R^{2}=0.69$, however, varying largely from phase to phase. For the baseline period of 1951-1968, before the construction of Danjiangkou Reservoir, the Hanjiang was the largest sediment supplier to the Changjiang below Yichang; therefore, for that period, the correlation between sediment discharge at Yichang and that at Datong was low $\left(R^{2}=0.52\right)$. It became higher, however, during the first phase $\left(R^{2}=0.69\right)$, and then reaching 0.89 remarkably during the second phase, as the sediment input from the Hanjiang had practically stopped (Figure 7).

[33] On the basis of the sediment data at Yichang and Datong from 1986 to 2002, the linear regression equation, calculated after excluding the flooding effect of 1998, is as follows.

$$
\mathrm{QsD}=0.489 \mathrm{QsY}+144
$$

where QsD and QsY are annual sediment loads at Datong station and Yichang station, respectively.

[34] The recently released sediment records of 2003 and 2004 at Yichang and Datong were used to verify the validity of this equation. The annual sediment loads at Yichang were $98 \mathrm{mt}$ and $64 \mathrm{mt}$ in 2003 and 2004, consequently, the predicted sediment loads at Datong are $190 \mathrm{mt}$ in 2003 and $175 \mathrm{mt}$ in 2004, while the measured sediment loads at Datong were $210 \mathrm{mt}$ and $150 \mathrm{mt}$, respectively. It is reasonable to assume that this equation is adequate for estimating the Changjiang sediment load at Datong after TGD completion since it takes into account for the whole present water and sediment situation of the Changjiang. 

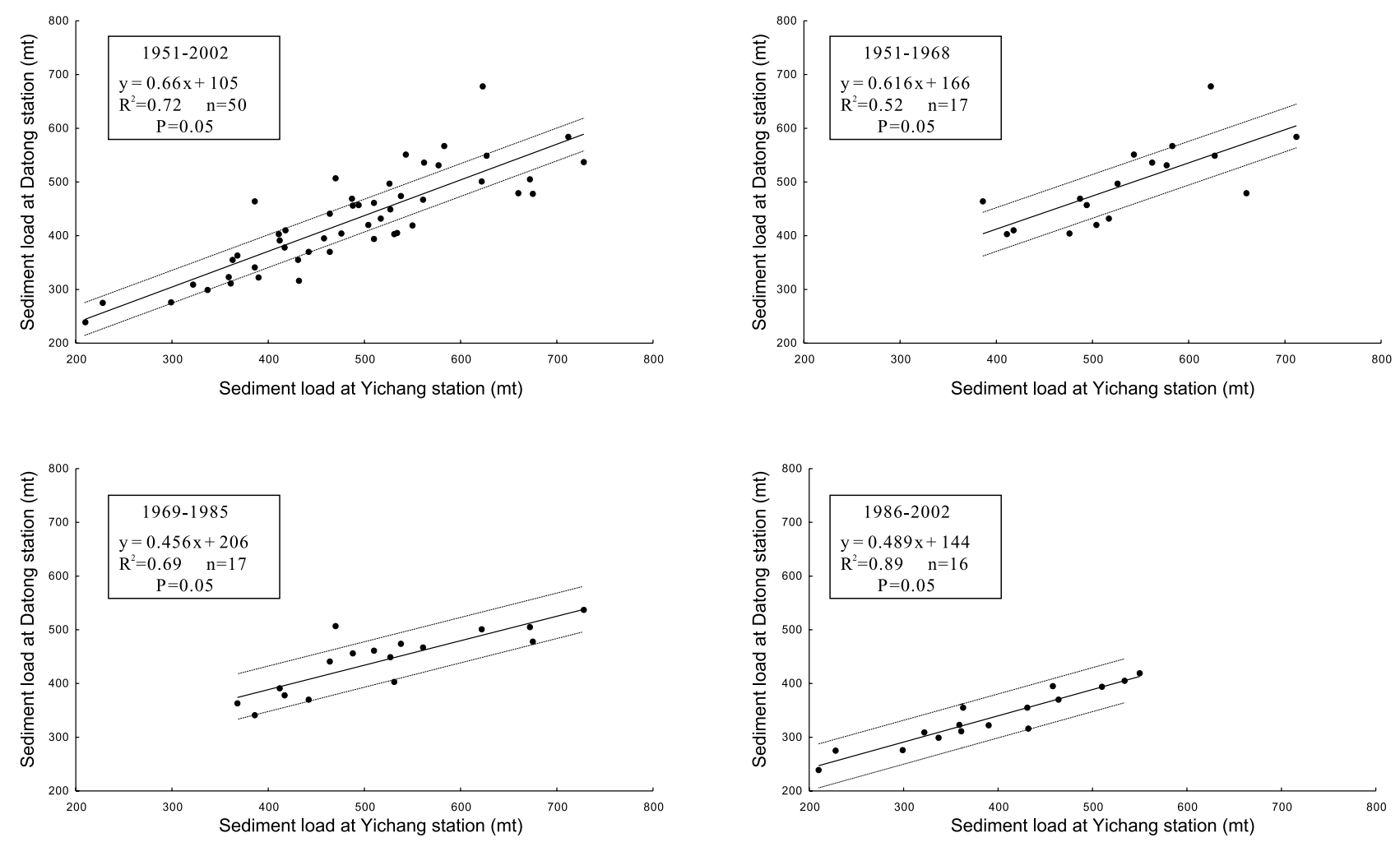

Figure 7. Correlations between annual sediment loads at Yichang and Datong gauging stations at different time periods.

[35] During the flood years of 1954 and 1998, a large amount of sediment was lost in the middle reaches through the river breaches and overbank flows, especially in the Jingjiang fluvial plain (Figure 4), as indicated by the high sediment loads at Yichang and low sediment loads at Luoshan, Hankou and Datong (Figure 3). The amount of overbank deposition in the middle and lower reaches can be estimated by equation (1). For the flood year of 1954, during which the measured sediment load at Yichang was $750 \mathrm{mt}$, the equation predicts a sediment load at Datong of $510 \mathrm{mt}$. The measured sediment load at Datong in 1954 was $460 \mathrm{mt}$. If the additional sediment input of $65 \mathrm{mt}$ (records at Xiantao gauge) from the Hanjiang were taken into account, the sediment lost in the middle reaches would be $115 \mathrm{mt}$. In 1998 the Hanjiang input almost stopped, and the predicted sediment load at Datong is $510 \mathrm{mt}$, nearly $110 \mathrm{mt}$ higher than the actual record of $400 \mathrm{mt}$. During the flood of 1998 the flooded area in the Jingjiang fluvial plain was more than $600 \mathrm{~km}^{2}$ (Figure 4), and the overbank deposition in Hubei Province was more than $60 \mathrm{mt}[X u, 2000]$. Therefore the predictions suggested that $\sim 100 \mathrm{mt}$ were lost to overbank deposition between the two hydrologic stations during the flood years.

\section{Estimated Impact of the Three Gorges Dam on Changjiang Sediment Discharge to the East China Sea}

\subsection{Impact of TGD Sediment Trapping}

[36] The reservoir behind TGD, which began filling in 2003 and initiated a third phase of sediment reduction for the Changjiang, will have a water storage capacity of $39 \mathrm{~km}^{3}$ and a dead storage capacity of $17 \mathrm{~km}^{3}$. Of the sediment entering the reservoir during the first 20 years after the TGD's completion in 2009, it is estimated that only $30 \%$ will be discharged from the dam, the remaining $70 \%$ being retained within the reservoir. This means that sediment discharge at Yichang will be reduced to $30 \%$ of its input value. From 2030 to 2060 , about $56 \%$ of the sediment will be retained, and by $2060-2110$ the proportion of sediment trapped within the reservoir will be reduced to $19 \%$ (Table 4) [Yang et al., 2002].

[37] Assuming the amount of sediment entering the reservoir of TGD is similar to the measured sediment load at Yichang during Phase 2 (1986-2002: $410 \mathrm{mt} / \mathrm{yr}$; see Table 2), the amount of sediment passing Yichang would be $130 \mathrm{mt} / \mathrm{yr}$ during the first 20 years after completion of the dam, $180 \mathrm{mt} / \mathrm{yr}$ for the next 30 years, and $330 \mathrm{mt} / \mathrm{yr}$ between 2060 and 2110 (Table 4). The amount of riverbed erosion below Yichang should decrease with time as a new equilibrium is reached, and sediment should begin accumulating as sediment discharge from the TGD increases.

[38] Yang et al. [2003] also have predicted the Changjiang sediment discharge to the East China Sea for the ten decades after TGD completion on the basis of the observed decrease in sediment loads from Yichang to Datong (their $\left.\mathrm{R}^{2}=0.64\right)$. However using the above approach, our predictions are greater than those of Yang et al. by about $25 \%(50 \mathrm{mt} / \mathrm{yr})$ on average (Table 4$)$. In part this is based on a better correlation between Yichang and Datong, since we have excluded the anomalous flood years of 1954 and 1998, increasing the $\mathrm{R}^{2}$ to 0.89 as the TGD is designed to prevent 
the effects of such extreme flooding, they can be discounted, as we have done in our calculations. Further more, the sediment input from Hanjiang has been almost stopped. On the basis of the relations between sediment loads at Yichang and Datong, we estimated that during the first 20 years after the TGD's completion $(2010-2030)$ the annual sediment loads at Datong would be $210 \mathrm{mt} / \mathrm{yr}$, then increase slightly to $230 \mathrm{mt} / \mathrm{yr}$ during the next 30 years (2030-2060) and finally approach $310 \mathrm{mt} / \mathrm{yr}$ (Table 4), near quantity of the second phase (Table 2).

\subsection{Impact of Riverbed Scouring}

[39] Because of the $70 \%$ reduction in sediment reaching the Changjiang downstream of the TGD (Table 4), increased riverbed scouring is expected. Using one-dimensional models, the Changjiang Academy of Science and the Changjiang Institute of Water Conservancy and Hydroelectric Science calculated that there would be extensive scouring for about $230 \mathrm{~km}$ downstream of the dam for the first decade, whereas accumulation would occur further downstream. Scouring would gradually extend downstream after the first 50 years, reaching its maximum extent after about 60 years, after which net accumulation would begin to exceed net erosion [Li et al., 1997]. Using these erosion accumulation predictions in decadal intervals for the first 80 years after TGD completion, we calculated additional Changjiang sediment supply from riverbed scouring. If the bulk density of the river sediment was taken as $1.35 \mathrm{t} / \mathrm{m}^{3}$ [Shi et al., 2002], the estimated sediment load at Datong during different time periods after the TGD's completion were quite close to the results from equation (1) (Table 4).

\subsection{Possible Deltaic Erosion Resulting From Reduction in Changjiang Sediment Discharge}

[40] According to a preliminary sediment budget proposed by Milliman et al. [1985], more than $40 \%$ of the sediment passing Datong station is deposited in the Changjiang estuary. Of the $60 \%$ escaping to the East China Sea, DeMaster et al. [1983] estimated that about $40 \%$ is deposited on the inner shelf north of $30^{\circ} \mathrm{N}$, but that much of that is resuspended and transported southward during winter storms. The stratigraphical study of the Changjiang delta also proposed that $\sim 47 \%$ of the Changjiang sediment deposited in the delta area [Liu et al., 2006], including $\sim 10 \%$ depositing in the segment between Datong and the Changjiang estuary [Shen, 2001]. Natural deltaic erosion, according to Yang et al. [2002], is about 100 to $150 \mathrm{mt} / \mathrm{yr}$. The average annual erosion of the Changjiang estuary and its subaqueous delta can be estimated as $125 \mathrm{mt} / \mathrm{yr}$ that consisted $\sim 40 \%$ of the sediment load at Datong. Therefore the critical sediment load at Datong for keeping balance of the Changjiang estuary and its delta would be $310 \mathrm{mt} / \mathrm{yr}$.

[41] During the first 20 years after TGD's completion, the annual sediment load passing Datong is estimated as $210 \mathrm{mt} / \mathrm{yr}$ (Table 4), much less than the critical value. Thus the Changjiang estuary would be deepened and its subaqueous delta would be eroded during this period. As the sediment discharge ratio from the TGR increased, the annual sediment load at Datong would increase correspondingly, to $230 \mathrm{mt} / \mathrm{yr}$ during the next three decades (2030-2060) and to $310 \mathrm{mt} / \mathrm{yr}$ during the five decades of 
2060-2110 (Table 4), implying that the Changjiang delta would gradually approach an approximate equilibrium.

\section{Conclusions}

[42] Between 1969 and 2002 sediment discharge from the Changjiang decreased by $\sim 25 \%$ in two reduction phases, although water discharge actually increased slightly. From a baseline sediment load of $490 \mathrm{mt} / \mathrm{yr}$ recorded at Datong between 1950 and 1968, over the following 17 years (1969-1985) the mean annual load decreased to $440 \mathrm{mt} / \mathrm{yr}$, followed by a 17 year interval (1986-2002) during which the mean annual load was $340 \mathrm{mt} / \mathrm{yr}$, and dramatically decreased to $180 \mathrm{mt} / \mathrm{yr}$ in the recent years of 2003 and 2004. The first reduction phase was mainly the result of the activation of the Danjiangkou Reservoir on the Hangjiang tributary; the second one caused mainly by construction of numerous dams and reservoirs as well as a water-soil conservation plan on the Jialingjiang tributary in the upper reaches; the last one was resulted from the TGD's impact as well as the sediment decrease in the tributaries of the upper Changjiang that continued from the second phase.

[43] On the basis of a relationship between sediment discharge at Yichang and Datong gauging stations, we calculate that sediment discharge from the Changjiang to the East China Sea will decrease to $210 \mathrm{mt} / \mathrm{yr}$ for the first 20 years following completion of the Three Gorges Dam (TGD), 2010-2030, and then recover to $230 \mathrm{mt} / \mathrm{yr}$ between 2030 and 2060 , and to $310 \mathrm{mt} / \mathrm{yr}$ for the next 50 years (2060-2110).

[44] Assuming the critical discharge of sediment past Datong to maintain the Changjiang delta to be $310 \mathrm{mt} / \mathrm{yr}$, for the first two decades after TGD completion, there should be extensive erosion, but the erosion accumulation should gradually balance out by 2060 . However, for the first 50 years after TGD completion, we hypothesize that the Changjiang deltaic area should undergo significant morphologic and environmental change because of local and regional erosion.

[45] Acknowledgments. The authors gratefully acknowledged the funding of this study by the National Science Foundation of China (NSFC) with grant 90211022 . We would like to thank Q. Xu from the Changjiang Water Resource Commission (CWRC) for fruitful discussions. Thanks are also extended to R. H. Meade and the two anonymous reviewers whose comments helped to improve the original manuscript.

\section{References}

Chen, J., and S. Chen (2002), Impacts of the south-to-north water transfer project on ecological environment at the Yangtze River estuary (in Chinese with English abstract), Water Resour. Prot., 3, 10-13.

Chen, Z., J. Li, H. Shen, and Z. Wang (2001), Yangtze River of China: Historical analysis of discharge variability and sediment flux, Geomorphology, 41, 77-91.

DeMaster, D. J., B. A. McKee, C. A. Nittrouer, J. C. Qian, and G. D. Cheng (1983), Rates of sediment accumulation and particle reworking based on radiochemical profiles from continental shelf deposits in the East China Sea, in Proceedings of the International Symposium on the Continental Shelf, With Special Reference to the East China Sea, vol. 2, pp. 581-605, China Ocean Press, Beijing.

Han, Q., and K. Yang (2000), The tendency of river pattern variation in the lower Jingjiang River after completion of the Three Gorges project (in Chinese with English abstract), J. Sediment. Res., 3, 1-11.

Higgitt, D., and X. Lu (2001), Sediment delivery to the three gorges: 1. Catchment controls, Geomorphology, 41, 143-156.

International Research and Training Center on Erosion and Sedimentation (IRTCES) (2000), River sediment bulletin of China 2000, Beijing. (Available at http://www.irtces.org/database.asp)
International Research and Training Center on Erosion and Sedimentation (IRTCES) (2001), River sediment bulletin of China 2001, Beijing. (Available at http://www.irtces.org/database.asp)

International Research and Training Center on Erosion and Sedimentation (IRTCES) (2002), River sediment bulletin of China 2002, Beijing. (Available at http://www.irtces.org/database.asp)

International Research and Training Center on Erosion and Sedimentation (IRTCES) (2003), River sediment bulletin of China 2003, Beijing. (Available at http://www.irtces.org/database.asp)

Li, A. (1997), Sediment Studies on the Three Gorges Project (in Chinese), Sci. and Technol. Press of Hubei Prov., Wuhan, China.

Li, Y., R. Li, and J. Deng (2000), A study on sediment transport and flood control in the middle reach of Yangtze River (in Chinese with English abstract), J. Sediment. Res., 3, 12-20.

Liu, D., M. Xiong, and W. Dong (1998), Channel erosions of the lower Hanjiang before and post Danjiangkou reservoir (in Chinese), Express Water Resour. Hydropower Inf., 19(23), 23-26.

Liu, J. P., A. C. Li, K. H. Xu, Z. S. Yang, D. M. Velozzi, J. D. Milliman, and D. J. DeMaster (2006), Sedimentary features of the Yangtze Riverderived alongshore clinoform deposit in the East China Sea, Continental Shelf Research, in press.

Lu, X., and D. Higgitt (2001), Sediment delivery to the Three Gorges: 2: Local response, Geomorphology, 41, 157-169.

Mao, H., and M. Pei (2002), Influence of human activities on runoff and sediment transmitting in Jialingjiang valley (in Chinese with English abstract), J. Soil Water Conserv., 16(5), 101-104.

Meade, R. H., and R. Parker (1985), Sediments in rivers of the United States, in National Water Summary 1984, U.S. Geol. Surv. Water Supply Pap. 2275, 49-60.

Meybeck, M. (2003), Global analysis of river systems: From Earth system controls to Anthropocene syndromes, Philos. Trans. R. Soc. London, Ser. $B, 358,1935-1955$, doi:10.1098/rstb.2003.1379.

Meybeck, M., and C. Vorosmarty (2005), Fluvial filtering of land-ocean fluxes: From natural Holocene variations to Anthropocene, C. R. Geosci., $337,107-123$.

Milliman, J. D., and J. P. M. Syvitski (1992), Geomorphic/tectonic control of sediment discharge to the ocean: The importance of small mountainous rivers, J. Geol., 100, 525-544.

Milliman, J. D., H. Shen, Z. Yang, and R. H. Meade (1985), Transport and deposition of river sediment in the Changjiang estuary and adjacent continental shelf, Continental Shelf Res., 4(1), 37-45.

Shen, H. (2001), Materials Flux of the Changjiang Estuary (in Chinese), pp. 21-24, China Ocean Press, Beijing.

Shi, G., Q. Xu, and Z. Chen (2002), Analysis on channel scouring and silting and self-adjusting in midstream and downstream reaches of Changjiang River, J. Mt. Res., 2002(3), 257-265.

United Nations Department of Economic and Social Affairs (2001), World population prospects (the 2000 revision), New York.

Wen, F., C. Yao, S. Cao, and B. Chen (1999), Atlas of the Changjiang River Basin (in Chinese), Sinomaps Press, Beijing.

$\mathrm{Xu}$, A. (2000), The Flood of the Yangtze River and Hydrographic Monitoring-Predicting in 1998 (in Chinese), China Water Power Press, Beijing.

$\mathrm{Xu}$, J. (2000), Runoff and sediment variation in the upper reaches of the Changjiang River and its tributaries due to deforestation (in Chinese with English abstract), J. Hydraul., 1, 72-80.

Yang, S., Q. Zhao, and I. Belkin (2002), Temporal variation in the sediment load of the Yangtze River and the influences of human activities, J. Hydrol., 263, 56-71.

Yang, S., I. Belkin, A. Belkin, Q. Zhao, J. Zhu, and P. Ding (2003), Delta response to decline in sediment supply from the Yangtze River: Evidence of the recent four decades and expectations for the next half-century, Estuarine Coastal Shelf Sci., 56, 1-11.

Zhang, J., Y. Ju, and Z. Zhang (1995), Nationwide river chemistry trends in China: Huanghe and Changjiang, Ambio, 24(5), 275-279.

J. D. Milliman and $\mathrm{K}$. Xu, Virginia Institute of Marine Science, Gloucester Point, VA 23062, USA.

S. Qiao, H. Wang, and Z. Yang, College of Marine Geosciences, Ocean University of China, Qingdao 266003, China. (zshyang@mail.ouc.edu.cn) Y. Saito, AIST, Geological Survey of Japan, Tsukuba 305-8567, Japan. G. Shi, Changjiang Water Resource Commission, Wuhan 430010, China. 